\title{
Understanding neuromuscular disorders in chronic fatigue
}

\section{syndrome [version 1; peer review: 2 approved]}

\author{
Yves Jammes (i1), Frédérique Retornaz² \\ ${ }^{1}$ C2VN Inserm Inra, Faculty of Medicine, Aix Marseille University, Marseille, France, France \\ ${ }^{2}$ Department of Internal Medicine, European Hospital, Marseille, France, France
}

V1 First published: 28 Nov 2019, 8(F1000 Faculty Rev):2020

https://doi.org/10.12688/f1000research.18660.1

Latest published: 28 Nov 2019, 8(F1000 Faculty Rev):2020

https://doi.org/10.12688/f1000research.18660.1

\section{Abstract}

Muscle failure has been demonstrated in patients with myalgic encephalomyelitis/chronic fatigue syndrome (ME/CFS).

Neurophysiological tools demonstrate the existence of both central and peripheral fatigue in these patients. Central fatigue is deduced from the reduced amplitude of myopotentials evoked by transcranial magnetic stimulation of the motor cortex as well as by the muscle response to interpolated twitches during sustained fatiguing efforts. An impaired muscle membrane conduction velocity assessed by the reduced amplitude and lengthened duration of myopotentials evoked by direct muscle stimulation is the defining feature of peripheral fatigue. Some patients with ME/CFS show an increased oxidative stress response to exercise. The formation of lipid hydroperoxides in the sarcolemma, which alters ionic fluxes, could explain the reduction of muscle membrane excitability and potassium outflow often measured in these patients. In patients with ME/CFS, the formation of heat shock proteins (HSPs) is also reduced. Because HSPs protect muscle cells against the deleterious effects of reactive oxygen species, the lack of their production could explain the augmented oxidative stress and the consecutive alterations of myopotentials which could open a way for future treatment of ME/CFS.

\section{Keywords}

myalgic encephalomyelitis, chronic fatigue syndrome, central fatigue, peripheral fatigue, oxidative stress, heat shock proteins, neurophysiology, physiology, neuromuscular disorders

\section{Open Peer Review}

Approval Status

1 2

version 1

28 Nov 2019

Faculty Reviews are review articles written by the prestigious Members of Faculty Opinions. The articles are commissioned and peer reviewed before publication to ensure that the final, published version is comprehensive and accessible. The reviewers who approved the final version are listed with their names and affiliations.

1. Brett A Lidbury, The Australian National

University, Canberra, Australia

2. Christopher R Snell, Workwell Foundation, Ripon, USA

Any comments on the article can be found at the end of the article. 
Corresponding author: Yves Jammes (yves.jammes@univ-amu.fr)

Author roles: Jammes Y: Conceptualization, Data Curation, Investigation, Methodology, Resources, Writing - Original Draft Preparation, Writing - Review \& Editing; Retornaz F: Conceptualization, Formal Analysis, Funding Acquisition, Resources, Supervision, Writing Original Draft Preparation, Writing - Review \& Editing

Competing interests: No competing interests were disclosed.

Grant information: The author(s) declared that no grants were involved in supporting this work.

Copyright: (c) 2019 Jammes $Y$ and Retornaz F. This is an open access article distributed under the terms of the Creative Commons Attribution License, which permits unrestricted use, distribution, and reproduction in any medium, provided the original work is properly cited.

How to cite this article: Jammes $Y$ and Retornaz F. Understanding neuromuscular disorders in chronic fatigue syndrome [version 1; peer review: 2 approved] F1000Research 2019, 8(F1000 Faculty Rev):2020 https://doi.org/10.12688/f1000research.18660.1

First published: 28 Nov 2019, 8(F1000 Faculty Rev):2020 https://doi.org/10.12688/f1000research.18660.1 


\section{Introduction}

Chronic fatigue syndrome (CFS), also called myalgic encephalomyelitis/CFS (ME/CFS), is a multisystem disease with immune dysfunction and autonomic abnormalities characterized by an intense fatigue worsened by physical/mental activity ${ }^{1,2}$. It is often associated with post-exertional malaise $(\mathrm{PEM})^{2,3}$. Its pathogenesis appears to have a number of factors; different stressors (such as physical exertion, severe infections, or emotional stress or a combination of these) are continually reported in the medical history of patients with $\mathrm{ME} / \mathrm{CFS}^{4}$. An altered skeletal muscle function has been observed in ME/CFS pathogenesis $^{5-9}$. In our studies ${ }^{5-8}$, alterations of the muscle membrane excitability in response to exercise was found in 86 out of 133 patients with ME/CFS (that is, 65\%). Several $\mathrm{ME} / \mathrm{CFS}$ studies have also reported an enhanced oxidative stress in response to exercise ${ }^{4-7}$. This mini-review focuses on the neurophysiological disorders found in patients with ME/CFS and changes in biochemical markers of exercise, such as the potassium outflow, oxidative stress, and heat shock protein (HSP) response.

\section{The general mechanisms of muscle fatigue}

Muscle fatigue results primarily from the incapacity of the muscle fibers to contract. Muscle failure called "peripheral fatigue" may result from a failure of different metabolic processes such as the imbalance between oxygen demand and supply, the reduced excitation-contraction coupling involving altered intracellular calcium release and mobilization, and the impaired muscle membrane excitability due to the altered flux of potassium through the sarcolemma ${ }^{10}$. "Peripheral fatigue" is generally preceded by the reduced recruitment of motoneurons which drive the highly fatiguing motor units. This phenomenon, called "central fatigue", tends to delay the occurrence of "peripheral fatigue" (the "muscle wisdom" phenomenon). In humans, non-invasive tools are used to explore "peripheral" and "central" fatigue. Peripheral fatigue is assessed by the reduction of the contractile response (twitch) to direct electrical muscle stimulation. On the other hand, central fatigue is present when the interpolation of twitches elicited by repetitive electrical muscle stimulation or transcranial magnetic stimulation (TMS) of cortical motor areas restores a contractile response during fatiguing efforts. Muscle fatigue is closely linked to an excessive production of reactive oxygen species $(\mathrm{ROS})^{11}$. The sensory pathways carried by the group III and IV muscle afferents play key reflex roles in triggering the muscle wisdom phenomenon. The motor drive of both working and resting muscles is modulated by these muscle afferents through their spinal and supraspinal projections and their afferent pathways, supporting the sensation of muscle fatigue and pain $^{12,13}$. Multiple stressors, such as fatiguing muscle contraction, muscle acidosis, hypoxia, ischemia, and ROS, stimulate these muscle afferents ${ }^{14-16}$. Their activation by muscle fatigue triggers the widespread production of $\operatorname{HSPs}^{17}$.

\section{In patients with myalgic encephalomyelitis/chronic} fatigue syndrome, central and peripheral fatigue coexist Central fatigue

Some physiological studies using the twitch interpolation technique and analyzing the maximal voluntary contraction cannot support the hypothesis of central fatigue in patients with $\mathrm{ME} / \mathrm{CFS}^{18,19}$. By contrast, numerous studies support the existence of central fatigue in these patients. Kent-Braun et al..$^{20}$ showed that the voluntary contraction of the tibialis muscle during maximal isometric exercise was lowered. In patients with post-infectious CFS, Sacco et al. ${ }^{21}$ reported a reduced amplitude of motor potentials evoked by TMS of the motor cortex in the biceps brachii muscle. The authors also reported an increased interpolated twitch amplitude during sustained fatiguing efforts in patients with ME/CFS. The same observations were made by Schillings et al..$^{22}$. Davey et al. ${ }^{23}$ correlated day-to-day changes in ME/CFS symptomatology with the changes in simple reaction times (SRTs) and movement times of myopotentials evoked in muscles by TMS of the motor cortex, and corticospinal excitability was assessed by measuring the threshold TMS intensity. The authors reported slowed SRTs and increased threshold intensity, supporting the existence of a deficit in motor preparatory cortical areas. Siemionow et al..$^{24}$ reported a modification of the central motor command to muscles during isometric handgrip and measured an increased relative power of electroencephalography theta frequency band in patients with ME/CFS compared with healthy volunteers. These observations suggest that ME/CFS pathology may be associated with an altered central nervous system command to muscles.

Perception of effort and pain seems to be accentuated in patients with ME/CFS. This was previously reported by Sacco et $a{ }^{21}$ and more recently confirmed ${ }^{25}$. The group III or IV metabosensitive muscle afferents present in all skeletal muscles are strongly activated by the oxygen free radicals ${ }^{16}$, a situation amplified in patients with $\mathrm{ME} / \mathrm{CFS}^{5,6}$. It is tempting to speculate that increased activation of muscle afferents in patients with ME/CFS could result in an accentuated perception of effort and pain (myalgia). The key role played by these muscle afferents in central fatigue (muscle wisdom phenomenon) could also explain the numerous observations of a diminished central activation, documented in $\mathrm{ME} / \mathrm{CFS}^{20-24}$.

\section{Peripheral fatigue}

Delayed recovery from fatiguing exercise in patients with ME/CFS may be due to peripheral muscle fatigue ${ }^{9,26}$. During incremental cycling leg exercise approaching the maximal oxygen uptake $\left(\mathrm{VO}_{2}\right)$, marked alterations of myopotentials in response to direct muscle stimulation (M-wave) have been observed in a number of patients with $\mathrm{ME} / \mathrm{CFS}^{5-8}$. These M-wave changes began early in exercise and culminated at the end of a 30-min recovery. This suggests the existence of peripheral fatigue due to impaired muscle membrane excitability. Similar M-wave alterations are absent in healthy subjects, for whom the amplitude of myopotentials either does not vary or even increases with the incremental pedaling force ${ }^{5}$.

\section{Biological events accompanying the electrophysiological disorders}

Reduced ionic fluxes through the muscle membrane

Alteration of ionic fluxes through the sarcolemma could explain the altered muscle membrane excitability reported in patients with ME/CFS. In healthy subjects, muscle biopsies demonstrated a physiological contraction-induced loss in myoplasmic 
potassium $\left(\mathrm{K}^{+}\right)$concentration ${ }^{27}$. This potassium outflow is detectable in plasma, and the kinetics of plasma $\mathrm{K}^{+}$increase during and after an incremental exercise is well known ${ }^{28}$. A study by Fulle et al. ${ }^{29}$ confirmed the presence of alterations in ryanodine channels and a deregulation of $\mathrm{Na}^{+} / \mathrm{K}^{+}$and $\mathrm{Ca}^{2+}$-ATPase pumps in the membranes of sarcoplasmic reticulum in patients with ME/CFS. To explain their data, Fulle et al. ${ }^{30}$ suggested that the deregulated pump activities could result from an increased fluidity of the sarcoplasmic reticulum membrane in these patients.

\section{Increased production of reactive oxygen species}

Several studies in patients with ME/CFS have examined changes in resting blood oxidant-anti-oxidant status and reported lower vitamin $\mathrm{E}$ concentration and higher levels of oxidized LDL, thiobarbituric acid reactive substances (TBARS), and malondialdehyde (MAL) $)^{31-33}$. In biopsies of vastus lateralis muscle of patients with ME/CFS, Fulle et al. ${ }^{30}$ detected oxidative damage to DNA and lipids and increased activity of intracellular anti-oxidants (catalase, glutathione peroxidase, and transferase). Other authors also found a correlation between musculoskeletal symptoms and an accentuated lipid peroxidation at rest in patients with ME/CFS ${ }^{33,34}$. Plasma markers of oxidative stress are the TBARS, a marker of lipid peroxidation, and reduced ascorbic acid, an endogenous anti-oxidant ${ }^{5-7,31-34}$.

In healthy subjects, exercise induces modest oxidative stress $^{5,35,36}$, whereas marked exercise-induced production of ROS has been found in patients with $\mathrm{ME} / \mathrm{CFS}^{5-7}$. The muscle production of oxygen free radicals is proportional to that of $\mathrm{VO}_{2}{ }^{35,36}$. From several reports ${ }^{5,37,38}, \mathrm{VO}_{2}$ measurement in exercising patients with ME/CFS indicated a normal aerobic function; indeed, their maximal $\mathrm{VO}_{2}$ was in the normal range. However, a recent study ${ }^{39}$ showed that, perhaps because of PEM, patients with ME/CFS were unable to reproduce cardiopulmonary exercise testing during a second test. An in vitro study in skeletal muscle cell culture ${ }^{40}$ showed that, after electrical pulse stimulation mimicking PEM, patients with ME/CFS, compared with normal subjects, had no increase in AMPK phosphorylation, a defect of glucose uptake, and a reduction of interleukin-6 (IL-6) secretion, highlighting the reality of lowered metabolic performance of muscle cells during PEM. A recent study by Richardson et al. ${ }^{41}$ proposed using the weighted standing time as a proxy for PEM severity in patients with ME/CFS.

An inhibitory action on $\mathrm{Na}^{+}-\mathrm{K}^{+}$pump activity is exerted by increased production of ROS during exercise ${ }^{11}$ and this reduces muscle membrane excitability and potassium outflow. Published $^{5-8}$ and unpublished observations have noted that the magnitude of altered muscle membrane excitability (reduced M-wave amplitude) is proportional to the reduction of exerciseinduced potassium outflow and to the magnitude of oxidative stress in patients with ME/CFS. Moreover, in $42 \%$ of the 69 patients with ME/CFS, PEM was associated with post-exercise alterations of muscle membrane excitability.

\section{Reduced heat shock protein production/expression}

The HSPs protect cells against the deleterious effects of ROS produced during exercise ${ }^{42,43}$, reducing the generation of ROS through the activation of anti-oxidants. The oxidant levels, in turn, increase the level of plasma $\mathrm{HSP}^{43}$. In patients with ME/CFS, the responses of plasma HSP27 and HSP70 to exercise can be delayed and often reduced, and resting levels of plasma HSP70 are lower in these patients than in healthy volunteers ${ }^{6}$. The lack of HSP response to exercise might explain the augmented oxidative stress measured in these patients. As already suggested ${ }^{7}$, a downregulation of HSP production in some individuals could be caused by the repetition of exercise bouts at high energetic levels. As cited above, the activation of the group III or IV muscle afferents triggers the HSP production in working and resting muscles as well as in the brain and different organs ${ }^{17}$. It may be hypothesized that the prolonged activation of these muscle afferents by the oxidative stress could induce a reduction of HSP production in patients with ME/CFS. Further studies, including in high-intensity sport programs and military training, are needed to show that the repetition of exercise bouts at high levels might depress the expression of the inducible factors of HSP However, HSP malfunction was also reported in different pathologies and may have origins other than the repetition of stressors. Thus, in patients with multiple sclerosis and systemic lupus erythematosus, Elfaitouri et al. ${ }^{44}$ measured an $\operatorname{IgM}$ to specific cross-reactive epitopes of human HSP60 compatible with infection-induced autoimmunity. HSP dysfunction was also reported in patients with chronic fatigue in primary Sjögren's syndrome ${ }^{45}$. Because antibodies to a microbial HSP60 may cross-react with human $\mathrm{HSP}^{46}$, it may be that infectious diseases often reported in patients with ME/CFS alter their HSP function.

\section{The role played by history of severe infections in the neuromuscular disorders of patients with myalgic encephalomyelitis/chronic fatigue syndrome}

In a previous study ${ }^{6}$, it was reported that the history of infection in patients with ME/CFS was associated with a marked significant increase in $\mathrm{M}$-wave alterations and a reduced exercise-induced potassium efflux. The post-exercise changes in $\mathrm{M}$-wave amplitude were correlated to a significant reduction of the maximal potassium outflow measured at the end of the exercise and to the baseline TBARS level. A further study highlights the importance of infectious stressors in ME/CFS pathogenesis and biological expression. A significant reduction of muscle excitability during work and increased blood oxidant status disorders at rest were measured in ME/CFS patients who reported a recent severe infection due to H1N1 influenza, pneumonia, encephalomyelitis, or sepsis ${ }^{7}$. It is well documented that acute infection constitutes a trigger for an oxidative stress $^{46-48}$. A review by Rasa et al. ${ }^{49}$ compiles all of the studies carried out so far to investigate various viral agents that could be associated with ME/CFS. However, the role played by viral infection in ME/CFS pathogenesis is not clear. Recent observations by Bouquet et al. ${ }^{50}$ do not support immune cell dysregulation or viral reactivation in ME/CFS patients after exercise bouts inducing PEM.

\section{Conclusions}

This review focuses on the neurophysiological modifications that associate central and peripheral fatigue, reduced potassium outflow from exercising muscles, altered equilibrium between 
pro- and anti-oxidants, and a reduced expression/production of HSPs in patients with ME/CFS. A mechanistic approach to the causes of neurobiological disorders in the ME/CFS pathology is proposed on the basis of a reduction in the protective role of HSP. Repeated and combined stressors (high exercise level, infections and perhaps also psychological stress) in the history of these patients might contribute to a depletion of HSP production or its expression or both. The consequences of a dysregulation of the oxidant/anti-oxidant status might result both in an altered muscle membrane excitability (peripheral fatigue) and in an augmented activation of the group III or IV muscle afferents which play a key role in the mechanism of central fatigue. Correcting any deficiency in HSP production could open a future way for the treatment of ME/CFS.

\section{Abbreviations}

HSP, heat shock protein; ME/CFS, myalgic encephalomyelitis/ chronic fatigue syndrome; M-wave, muscle action potential; PEM, post-exertional malaise; ROS, reactive oxygen species; SRT, simple reaction time; TBARS, thiobarbituric acid reactive substances; TMS, transcranial magnetic stimulation; $\mathrm{VO}_{2}$, oxygen uptake
1. Fukuda K, Straus SE, Hickie I, et al:: The chronic fatigue syndrome: a comprehensive approach to its definition and study. International Chronic Fatigue Syndrome Study Group. Ann Intern Med. 1994; 121(12): 953-9. PubMed Abstract | Publisher Full Text

2. Institute of Medicine of the National Academies: Beyond Myalgic Encephalomyelitis/Chronic Fatigue Syndrome: Redefining an Illness. Committee on the Diagnostic Criteria for Myalgic Encephalomyelitis/Chronic Fatigue Syndrome; Board on the Health of Select Populations. National Academics Press, Washington DC. 2015; www.nap-edu.

PubMed Abstract | Publisher Full Text

3. Carruthers BM: Definitions and aetiology of myalgic encephalomyelitis: how the Canadian consensus clinical definition of myalgic encephalomyelitis works. J Clin Pathol. 2007; 60(2): 117-9.

PubMed Abstract | Publisher Full Text | Free Full Text

4. Prins JB, van der Meer JWM, Bleijenberg G: Chronic fatigue syndrome. The Lancet. 2006; 367(9507): 346-55.

PubMed Abstract | Publisher Full Text

5. Jammes $Y$, Steinberg JG, Mambrini O, et al:: Chronic fatigue syndrome: assessment of increased oxidative stress and altered muscle excitability in response to incremental exercise. J Intern Med. 2005; 257(3): 299-310. PubMed Abstract | Publisher Full Text

6. Jammes $Y$, Steinberg JG, Delliaux S: Chronic fatigue syndrome: acute infection and history of physical activity affect resting levels and response to exercise of plasma oxidant/antioxidant status and heat shock proteins. $J$ Intern Med. 2012; 272(1): 74-84.

PubMed Abstract | Publisher Full Text

7. Fenouillet $\mathrm{E}$, Vigouroux A, Steinberg JG, et al:: Association of biomarkers with health-related quality of life and history of stressors in myalgic encephalomyelitis/chronic fatigue syndrome patients. J Trans/ Med. 2016; 14: 251.

PubMed Abstract | Publisher Full Text | Free Full Text

8. Jammes Y, Guillaume Steinberg J, Guieu R, et al.: Chronic fatigue syndrome with history of severe infection combined altered blood oxidant status, and reduced potassium efflux and muscle excitability at exercise. OJIM. 2013; 03(3): 98-105 Publisher Full Text

9. Samii A, Wassermann EM, Ikoma $\mathrm{K}$, et al: Decreased postexercise facilitation of motor evoked potentials in patients with chronic fatigue syndrome or depression. Neurology. 1996; 47(6): 1410-4. PubMed Abstract | Publisher Full Text

10. Enoka RM, Stuart DG: Neurobiology of muscle fatigue. J Appl Physiol. 1992; 72(5): 1631-48.

PubMed Abstract | Publisher Full Text

11. Juel C: Muscle fatigue and reactive oxygen species. J Physiol. 2006; 576(Pt 1): 1. PubMed Abstract | Publisher Full Text | Free Full Text

12. Ling LJ, Honda $T$, Shimada $Y$, et al.: Central projection of unmyelinated (C) primary afferent fibers from gastrocnemius muscle in the guinea pig. J Comp Neurol. 2003; 461(2): 140-50.

PubMed Abstract | Publisher Full Text

13. F Sidhu SK, Weavil JC, Mangum TS, et al.: Group III/IV locomotor muscle afferents alter motor cortical and corticospinal excitability and promote central fatigue during cycling exercise. Clin Neurophysiol. 2017; 128(1): 44-55. PubMed Abstract | Publisher Full Text | Free Full Text | F1000 Recommendation

14. Rotto DM, Kaufman MP: Effect of metabolic products of muscular contraction on discharge of group III and IV afferents. J Appl Physiol (1985). 1988; 64(6):
2306-13.

PubMed Abstract | Publisher Full Text

15. Decherchi $P$, Darques JL, Jammes $Y$ : Modifications of afferent activities from Tibialis anterior muscle in rat by tendon vibrations, increase of interstitial potassium or lactate concentration and electrically-induced fatigue. $J$ Peripher Nerv Syst. 1998; 3(4): 267-76. PubMed Abstract

16. Delliaux S, Brerro-Saby C, Steinberg JG, et al:: Reactive oxygen species activate the group IV muscle afferents in resting and exercising muscle in rats. Pflugers Arch. 2009; 459(1): 143-50.

PubMed Abstract | Publisher Full Text

17. Jammes $\mathrm{Y}$, Steinberg JG, Olivier M, et al:: The mechanisms of the widespread production of phosphorylated HSP25 after fatiguing muscle stimulation. J Exp Biol. 2013; 216(Pt 19): 3620-6. PubMed Abstract | Publisher Full Text

18. Lloyd AR, Gandevia SC, Hales JP: Muscle performance, voluntary activation, twitch properties and perceived effort in normal subjects and patients with the chronic fatigue syndrome. Brain. 1991; 114(Pt 1A): 85-98. PubMed Abstract

19. Stokes MJ, Cooper RG, Edwards RH: Normal muscle strength and fatigability in patients with effort syndromes. BMJ. 1988; 297(6655): 1014-7. PubMed Abstract | Publisher Full Text | Free Full Text

20. Kent-Braun JA, Sharma KR, Weiner MW, et al: Central basis of muscle fatigue in chronic fatigue syndrome. Neurology. 1993; 43(1): 125-31. PubMed Abstract | Publisher Full Text

21. Sacco P, Hope PA, Thickbroom GW, et al.: Corticomotor excitability and perception of effort during sustained exercise in the chronic fatigue syndrome. Clin Neurophysiol. 1999; 110(11): 1883-91. PubMed Abstract | Publisher Full Text

22. Schillings ML, Kalkman JS, van der Werf SP, et al:: Diminished central activation during maximal voluntary contraction in chronic fatigue syndrome. Clin Neurophysiol. 2004; 115(11): 2518-24. PubMed Abstract | Publisher Full Text

23. Davey NJ, Puri BK, Catley M, et al.: Deficit in motor performance correlates with changed corticospinal excitability in patients with chronic fatigue syndrome. Int J Clin Pract. 2003; 57(4): 262-4. PubMed Abstract

24. Siemionow V, Fang $\mathrm{Y}$, Calabrese $\mathrm{L}$, et al:: Altered central nervous system signal during motor performance in chronic fatigue syndrome. Clin Neurophysiol. 2004; 115(10): 2372-81. PubMed Abstract | Publisher Full Text

25. F Gerwyn M, Maes M: Mechanisms Explaining Muscle Fatigue and Muscle Pain in Patients with Myalgic Encephalomyelitis/Chronic Fatigue Syndrome (ME/CFS): a Review of Recent Findings. Curr Rheumatol Rep. 2017; 19(1): 1. PubMed Abstract | Publisher Full Text | F1000 Recommendation

26. Paul L, Wood L, Behan WM, et al: Demonstration of delayed recovery from fatiguing exercise in chronic fatigue syndrome. Eur J Neurol. 1999; 6(1): 63-9. PubMed Abstract | Publisher Full Text

27. Sjøgaard G: Exercise-induced muscle fatigue: the significance of potassium. Acta Physiol Scand Suppl. 1990; 593: 1-63. PubMed Abstract

28. Marcos E, Ribas J: Kinetics of plasma potassium concentrations during exhausting exercise in trained and untrained men. Eur J Appl Physiol Occup Physiol. 1995; 71(2-3): 207-14. PubMed Abstract | Publisher Full Text 
29. Fulle S, Belia S, Vecchiet J, et al:: Modification of the functional capacity of sarcoplasmic reticulum membranes in patients suffering from chronic fatigue syndrome. Neuromuscul Disord. 2003; 13(6): 479-84. PubMed Abstract | Publisher Full Text

30. Fulle $\mathrm{S}, \mathrm{Mecocci} \mathrm{P}$, Fanó G, et al:: Specific oxidative alterations in vastus lateralis muscle of patients with the diagnosis of chronic fatigue syndrome. Free Radic Biol Med. 2000; 29(12): 1252-9. PubMed Abstract | Publisher Full Text

31. Kennedy G, Spence VA, McLaren M, et al:: Oxidative stress levels are raised in chronic fatigue syndrome and are associated with clinical symptoms. Free Radic Biol Med. 2005; 39(5): 584-9.

PubMed Abstract | Publisher Full Text

32. Manuel y Keenoy B, Moorkens G, Vertommen J, et al.: Antioxidant status and lipoprotein peroxidation in chronic fatigue syndrome. Life Sci. 2001; 68(17): 2037-49.

PubMed Abstract | Publisher Full Text

33. Vecchiet J, Cipollone F, Falasca K, et al:: Relationship between musculoskeletal symptoms and blood markers of oxidative stress in patients with chronic fatigue syndrome. Neurosci Lett. 2003; 335(3): 151-4. PubMed Abstract | Publisher Full Text

34. Richards RS, Roberts TK, McGregor NR, et al.: Blood parameters indicative of oxidative stress are associated with symptom expression in chronic fatigue syndrome. Redox Rep. 2000; 5(1): 35-41. PubMed Abstract | Publisher Full Text

35. Steinberg JG, Ba A, Brégeon $F$, et al:: Cytokine and oxidative responses to maximal cycling exercise in sedentary subjects. Med Sci Sports Exerc. 2007; 39(6): 964-8.

PubMed Abstract | Publisher Full Text

36. Jammes $\mathrm{Y}$, Steinberg JG, Brégeon $\mathrm{F}$, et al: The oxidative stress in response to routine incremental cycling exercise in healthy sedentary subjects. Respir Physiol Neurobiol. 2004; 144(1): 81-90. PubMed Abstract | Publisher Full Text

37. Mullis R, Campbell IT, Wearden AJ, et al.: Prediction of peak oxygen uptake in chronic fatigue syndrome. Br J Sports Med. 1999; 33(5): 352-6. PubMed Abstract | Publisher Full Text | Free Full Text

38. Inbar O, Dlin R, Rotstein A, et al:: Physiological responses to incremental exercise in patients with chronic fatigue syndrome. Med Sci Sports Exerc. 2001; 33(9): 1463-70. PubMed Abstract | Publisher Full Text

39. F Stevens S, Snell C, Stevens J, et al:: Cardiopulmonary Exercise Test Methodology for Assessing Exertion Intolerance in Myalgic Encephalomyelitis/ Chronic Fatigue Syndrome. Front Pediatr. 2018; 6: 242.

PubMed Abstract | Publisher Full Text | Free Full Text | F1000 Recommendation
40. F Brown AE, Jones DE, Walker M, et al: Abnormalities of AMPK activation and glucose uptake in cultured skeletal muscle cells from individuals with chronic fatigue syndrome. PLoS One. 2015; 10(4): e0122982. PubMed Abstract | Publisher Full Text | Free Full Text | F1000 Recommendation

41. $\mathrm{F}$ Richardson AM, Lewis DP, Kita B, et al:: Weighting of orthostatic intolerance time measurements with standing difficulty score stratifies ME/CFS symptom severity and analyte detection. $J$ Trans/ Med. 2018; 16(1): 97 PubMed Abstract | Publisher Full Text | Free Full Text | F1000 Recommendation

42. Whitham M, Fortes MB: Heat shock protein 72: release and biological significance during exercise. Front Biosci. 2008; 13: 1328-39. PubMed Abstract | Publisher Full Text

43. Noble EG: Heat shock proteins and their induction with exercise. In: Exercise and Stress Response. Edited by Locke M, Noble EG. Boca Raton, London, New York, Washington DC: CRC Press, 2002; 43-78. Publisher Full Text

44. Elfaitouri A, Herrmann B, Bölin-Wiener A, et al:: Epitopes of microbial and human heat shock protein 60 and their recognition in myalgic encephalomyelitis. PLoS One. 2013; 8(11): e81155 PubMed Abstract | Publisher Full Text | Free Full Tex

45. F Bårdsen K, Nilsen MM, Kvaløy JT, et al:: Heat shock proteins and chronic fatigue in primary Sjögren's syndrome. Innate Immun. 2016; 22(3): 162-7. PubMed Abstract | Publisher Full Text | Free Full Text | F1000 Recommendation

46. Jones DB, Coulson AF, Duff GW: Sequence homologies between hsp60 and autoantigens. Immunol Today. 1993; 14(3): 115-8. PubMed Abstract | Publisher Full Text

47. Biagioli MC, Kaul P, Singh I, et al.: The role of oxidative stress in rhinovirus induced elaboration of IL-8 by respiratory epithelial cells. Free Radic Biol Med. 1999; 26(3-4): 454-62.

PubMed Abstract | Publisher Full Text

48. Choi AM, Knobil K, Otterbein SL, et al: Oxidant stress responses in influenza virus pneumonia: gene expression and transcription factor activation. $A m J$ Physiol. 1996; 271(3 Pt 1): L383-91. PubMed Abstract | Publisher Full Tex

49. F Rasa S, Nora-Krukle Z, Henning N, et al:: Chronic viral infections in myalgic encephalomyelitis/chronic fatigue syndrome (ME/CFS). J Transl Med. 2018; 16(1): 268.

PubMed Abstract | Publisher Full Text | Free Full Text | F1000 Recommendation

50. F Bouquet J, Li T, Gardy JL, et al.: Whole blood human transcriptome and virome analysis of ME/CFS patients experiencing post-exertional malaise following cardiopulmonary exercise testing. PLOS One. 2019; 14(3): e0212193. PubMed Abstract | Publisher Full Text | Free Full Text | F1000 Recommendation 


\section{Open Peer Review}

\section{Current Peer Review Status:}

\section{Editorial Note on the Review Process}

Faculty Reviews are review articles written by the prestigious Members of Faculty Opinions. The articles are commissioned and peer reviewed before publication to ensure that the final, published version is comprehensive and accessible. The reviewers who approved the final version are listed with their names and affiliations.

\section{The reviewers who approved this article are:}

\section{Version 1}

\section{Christopher R Snell}

Workwell Foundation, Ripon, CA, USA

Competing Interests: No competing interests were disclosed.

\section{Brett A Lidbury}

National Centre for Epidemiology and Population Health, RSPH, College of Health and Medicine, The Australian National University, Canberra, ACT, 2601, Australia

Competing Interests: No competing interests were disclosed.

The benefits of publishing with F1000Research:

- Your article is published within days, with no editorial bias

- You can publish traditional articles, null/negative results, case reports, data notes and more

- The peer review process is transparent and collaborative

- Your article is indexed in PubMed after passing peer review

- Dedicated customer support at every stage

For pre-submission enquiries, contact research@f1000.com 